\title{
Nutrient Removal from Modeling Effluent of Secondary Treatment Process by Unvegetated Vertical Flow Constructed Wetlands
}

\author{
You Lv \\ College of Environmental Science and Engineering \\ Beijing Forestry University \\ Beijing 100083, China \\ gelimuqiao90@163.com
}

Bin Zhou

The Administrative Center for China's Agenda 21

Beijing 100083, China

zhoubien@hotmail.com

\author{
Hong-jie Wang* \\ College of Environmental Science and Engineering \\ Beijing Forestry University \\ Beijing 100083, China \\ hongjiewang@bjfu.edu.cn
}

\begin{abstract}
Two types of unvegetated vertical flow constructed wetlands (UVFCWs) with zeolite and volcanic rock as composite substrates were constructed and the treatment performance for nutrient removal from modeling effluent of secondary treatment process was evaluated. The concentration of $\mathrm{COD}, \mathrm{NH}_{4}^{+}-\mathrm{N}, \mathrm{NO}_{3}^{-}-\mathrm{N}, \mathrm{NO}_{2}^{-}-\mathrm{N}$ and $\mathrm{DO}$ were detected at five shorter hydraulic retention times (HRT). At carbon nitrogen ratio of 4:1, HRT of 0.25-4 days and a hydraulic loading (HL) of $0.995-1.592 \mathrm{~m}^{3} \mathrm{~m}^{-2} \mathrm{~d}^{-1}$, the average COD concentration decreased from $60 \mathrm{mg} \mathrm{L}^{-1}$ in the influent to $30 \mathrm{mg} \mathrm{L}^{-1}$ in the effluent; the average $\mathrm{NH}_{4}^{+}-\mathrm{N}$ (ammonia) concentration decreased from $15 \mathrm{mg} \mathrm{L}^{-1}$ to $2 \mathrm{mg} \mathrm{L}^{-1}$, thus meeting the Class-IV surface water standards in China. At the experimental conditions, HRT had little effect on the removal of COD, but had obvious influence on the removal of $\mathrm{NH}_{4}^{+}-\mathrm{N}$. The concentrations of the $\mathrm{NH}_{4}^{+}-\mathrm{N}$, $\mathrm{NO}_{3}^{-}-\mathrm{N}$ and $\mathrm{NO}_{2}^{-}-\mathrm{N}$ in the effluents of different depth of the reactor were all in low values, and the concentration of DO were almost unchangeable. The high efficiency of nitrification, denitrification and annamox process in the zeolite and volcanic rock composite substrates system is account for the good performance of UVFCWs.
\end{abstract}

Keywords-vertical flow constructed wetlands; effluent of secondary treatment; COD removal; nitrogen removal; HRT.

\section{INTRODUCTION}

Traditionally, the main task of the municipal sewage treatment plant is to remove the colloidal or soluble organic compounds, so that the effluent can meet a certain emission standard. Although the wastewater is well treated in the secondary treatment process, high level of nutrients, such as $\mathrm{COD}, \mathrm{NH}_{4}{ }^{+}-\mathrm{N}$ and $\mathrm{P}$, bring potential risk to the receiving waterbody and the aquatic ecoenvironment [1].In order to meet increasingly strict emissions limits, tertiary sewage treatment is widely conducted to reduce the residual pollutant amount of the secondary effluent in many countries. Many advanced technologies, such as physic-chemical, electrochemical, biological, or ecological processes and so on, are developed for the sewage tertiary treatment. Especially, constructed wetlands (CWs), designed as an appropriate eco-system to remove pollutants from wastewaters, has stood out for low cost, simple operation and maintenance, little secondary pollution and favorable environmental appearance $[1,2]$.

According to different patterns of water flow, CWs can be divided into free-surface flow (FWS) and subsurface flow CWs. Subsurface flow CWs can further be divided into horizontal subsurface flow (HF)CWs[9] and vertical flow (VF) CWs[3].Different types of CWs have different structures, which lead to the differences of the mechanism and efficiency of pollutant removal. Because the vertical flow CWs provided more uniform water distribution, higher area utilization ratio and better internal oxygenation which favored the growth of aerobic microorganisms and the nitrification process thus ensured high elimination rate of the nitrogen organic matters, the number of this vertical flow CWs used for treating the domestic sewage was greatly higher than the other two types of CWs $[4,5]$.

There are many internal (e.g., plants, substrates, microorganisms) and external factors (e.g., $\mathrm{pH}$, dissolved oxygen, temperature, hydraulic retention time, operation mode, etc.) affecting the nitrogen and chemical oxygen demand (COD) removal ability of CWs. The objectives of the present study are (1) to reveal the effect of HRT and DO on the removal efficiency of nitrogen and COD; (2) to evaluate the performance of unvegetated vertical flow constructed wetlands(UVFCWs) on nutrient removal from modeling effluent of secondary treatment process.

\section{MATERials AND MethodS}

\section{A. Source of Wastewater}

The synthetic wastewater was prepared by dissolving the glucose, $\mathrm{NH}_{4} \mathrm{Cl}, \mathrm{KH}_{2} \mathrm{PO}_{4}$, and trace elements $\left(\mathrm{FeSO}_{4} \cdot 7 \mathrm{H}_{2} \mathrm{O}, \mathrm{MnCl}_{2} \cdot 4 \mathrm{H}_{2} \mathrm{O}, \mathrm{ZnSO}_{4}, \mathrm{CaCl}_{2}, \mathrm{CuSO}_{4} \cdot 5 \mathrm{H}_{2} \mathrm{O}\right.$, $\mathrm{H}_{3} \mathrm{BO}_{3}$, and $\mathrm{NiCl}_{2} \cdot \mathrm{H}_{2} \mathrm{O}$ ) into the distilled water. The 
concentrations of chemical oxygen demand (COD), total phosphorus (TP), and $\mathrm{NH}_{4}{ }^{+}-\mathrm{N}$ were preset as $60 \mathrm{mg} / \mathrm{L}, 1.0$ $\mathrm{mg} / \mathrm{L}$, and $15.0 \mathrm{mg} / \mathrm{L}$, respectively.

\section{B. Column Experiments}

The effect of composite substrates on nutrient removal was assessed in fixed-bed columns. The aqueous solutions were pumped through glass columns with an internal diameter of 0.8 and $400 \mathrm{~cm}$ length by using a peristaltic pump (Dinko, Spain). All the experiments were carried out at room temperature $\left(25 \pm 1{ }^{\circ} \mathrm{C}\right)$. Substrates, zeolite and volcanic rock, were loaded in the column with different weight ratio. The modeling wastewater was pumped in down-flow mode through the bed at a desired volumetric flow rate. The samples were collected every 12, 24, 48 and $72 \mathrm{~h}$, and the residual concentrations of the nutrients were detected.

\section{Unvegetated Vertical Flow Constructed Wetlands}

The schematic diagram of a simulated vertical flow wetland reactor is shown in Fig. 1. It was fabricated from polymethyl methacrylate with a diameter of $170 \mathrm{~mm}$, a height of $1160 \mathrm{~mm}$. Gravel $(\Phi 30-50 \mathrm{~mm})$ was added at the bottom of the columns as the support medium, the depth of this layer was $80 \mathrm{~mm}$. And a $960 \mathrm{~mm}$ depth of composite substrates was added as the main wetland medium layer, The composites of zeolite $(\Phi 10-30 \mathrm{~mm})$ and volcanic rock $(\Phi 30-50 \mathrm{~mm})$ with weight ratio of $1: 1$ and $3: 1$ are used as the substrates of theUVFCWs- 1 and UVFCWs-2.The depth of the surface layer which was filled with the smaller gravels of $5 \mathrm{~mm}$ in size was $80 \mathrm{~mm}$. The total volume of this reactor was $21.3 \mathrm{~L}$ and the effective volume was $8.3 \mathrm{~L}$ and $8.1 \mathrm{~L}$ [6].The influent was continuously introduced into the column from the top by a peristaltic pump, while the effluent was drained out. The desired hydraulic retention times (HRTs) were adjusted by controlling the flow rate of the influent.

\section{Start-up and Operating Strategies}

Approximately $10 \mathrm{~L}$ of activated sludge with the mixed liquor suspended solid of 4500-5000 $\mathrm{mg} / \mathrm{L}$ was inoculated into the wetland reactor, which was obtained from Gaobeidian Wastewater Treatment Plant, Beijing, China. After inoculation, the reactor was kept stationary for $24 \mathrm{~h}$. Then, the synthetic wastewater was fed into the reactor at the flow rate of $19.2 \mathrm{ml} / \mathrm{min}$. When the biofilm that adhered on the media was visible to the naked eyes and the removal efficiency of COD and $\mathrm{NH}_{4}{ }^{+}-\mathrm{N}$ kept stable for 10 days, the start-up period was finished.

After the start-up period, the synthetic wastewater was continuously introduced into the column. The hydraulic retention time was fixed on $0.25 \mathrm{~d}$ at the flow rate of 9.6 $\mathrm{ml} / \mathrm{min}$ at first, and then increased to $0.5,1,2$ and $4 \mathrm{~d}$ respectively. During the subsequent running days, the water temperature was at the range of 13.0 to $15.0^{\circ} \mathrm{C}$. Samples were collected from the influent and effluent from sampling points (SP) $\mathrm{A}, \mathrm{B}$ and $\mathrm{C}$ every day. The concentrations of $\mathrm{COD}, \mathrm{NH}_{4}^{+}-\mathrm{N}, \quad \mathrm{NO}_{3}^{-}-\mathrm{N}, \quad \mathrm{NO}_{2}^{-}-\mathrm{N}$, dissolved oxygen (DO), and $\mathrm{pH}$ were analyzed immediately after sampling.

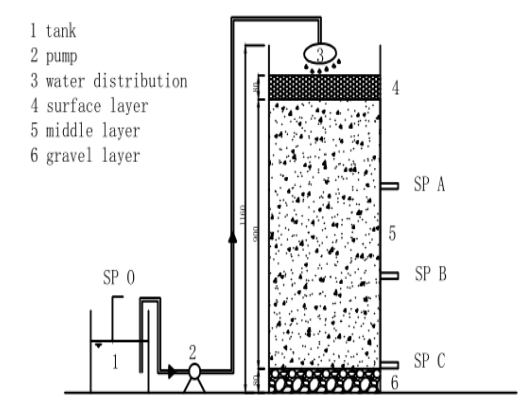

Figure 1. Schematic of the simulated wetland reactor, $\mathrm{SP}=$ Sampling Point.

\section{E. Analytical methods}

The COD level was measured using a COD analyzer (5B-3B, Beijing Lianhua Science Technology Co., China). The $\mathrm{NH}_{4}^{+}-\mathrm{N}, \mathrm{NO}_{2}{ }^{-}-\mathrm{N}$ and $\mathrm{NO}_{3}{ }^{-}-\mathrm{N}$ levels were detected using a spectrophotometer (UV-2000, Unico)according to national standard methods[6]. DO and $\mathrm{pH}$ were measured using a DO detector (Multi 3410, WTW Co., Germany) and a pH meter (PB-10, Sartorious Co., LTD., Germany), respectively. The presented data are the average values. The standard error deviation was about $10 \%[6]$.

\section{RESUlTS AND DisCUSSIONS}

\section{A. Fixed-bed Adsorption Experiments}
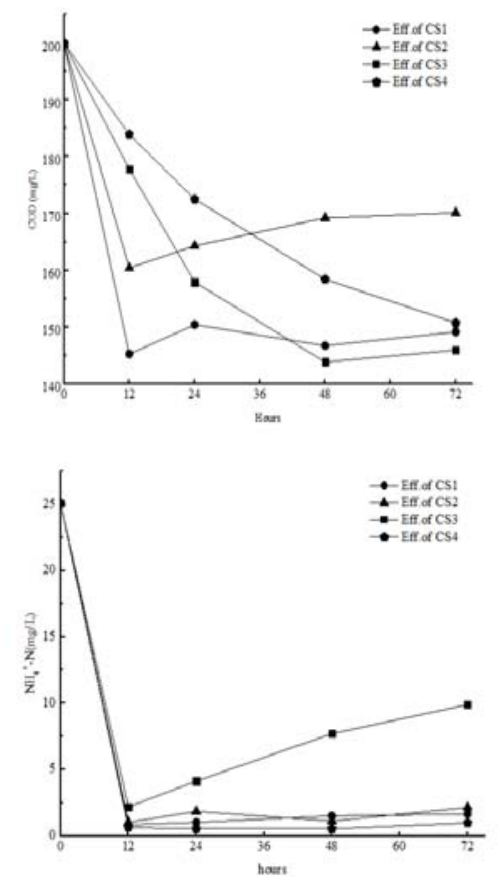

Figure 2. $\mathrm{COD}(\mathrm{A})$ and $\mathrm{NH}_{4}^{+}-\mathrm{N}(\mathrm{B})$ removal by different composite substrates

COD: $200 \mathrm{mg} / \mathrm{L} ; \mathrm{NH}_{4}^{+}-\mathrm{N}: 25 \mathrm{mg} / \mathrm{L}$

CS1: zeolite and volcanic rock with weight ratio of $1: 1$ CS2: zeolite and volcanic rock with weight ratio of $2: 1$ CS3: zeolite and volcanic rock with weight ratio of $1: 2$ CS4: zeolite and volcanic rock with weight ratio of $3: 1$ 
The effect of composition of the substrates on COD and $\mathrm{NH}_{4}^{+}-\mathrm{N}$ removal is illustrated in Fig.2 (A) and (B). To the composite substrates of zeolite and volcanic rock with weight ratio of 1:1, 2:1, 1:2 and 3:1 (CS1-CS4), prolonged contact time is good for COD removal, while the increasing ratio of zeolite has obviously negative effect on COD removal. The COD removal efficiency at $12 \mathrm{~h}$ is $7.5 \%, 11.5 \%$ and $27.5 \%$, respectively. Ascribing to the high adsorbing efficiency of zeolite, the $\mathrm{NH}_{4}{ }^{+}-\mathrm{N}$ concentrations in the effluents are as low as $0.5 \mathrm{mg} \mathrm{L}^{-1}$. Meanwhile, prolonged contact time and the increasing ratio of zeolite have no remarkable effect on $\mathrm{NH}_{4}{ }^{+}-\mathrm{N}$ removal. Based on the above results, the composites of zeolite and volcanic rock with weight ratio of $1: 1$ and $3: 1$ are used as the substrates of the unvegetated vertical flow constructed wetlands (UVFCWs) to further detect the performance of nutrients removal.

\section{B. Effect of HRT on COD Removal by UVFCWs}

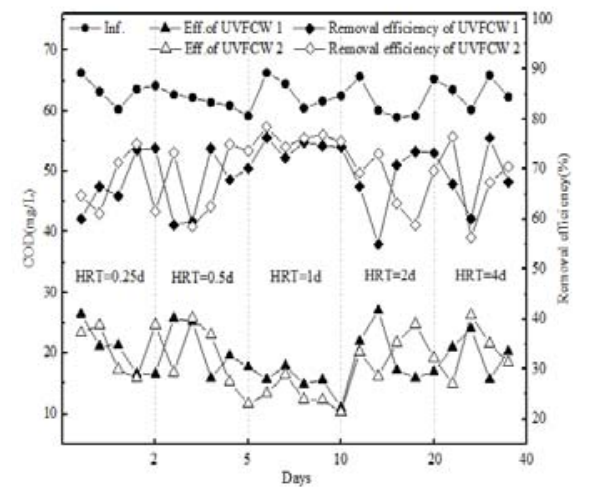

Figure 3. Effect of HRT on COD removal by UVFCWs

After the start-up period, the wastewater is continuously introduced to the UVFCWs. The HRT is fixed on $0.25 \mathrm{~d}$ at the initial and then increased to $0.5,1,2$ and $4 \mathrm{~d}$, respectively, during the subsequent $40 \mathrm{~d}$. As shown in Fig.3, the average concentration of COD in the effluent wastewater varied little betweenUVFCWs-1 and UVFCWs-2 with different HRTs. Although the removal efficiency of COD is fluctuated at lower HRTs, the average results are at the range of $60 \%$ to $70 \%$. To the UVFCWs with different composite substrates, the HRT has no significant influence on the removal of COD, which indicates a good cooperation between physical and microbial processes in the UVFCWs. This can be ascribed to the accumulation of immense amounts of attached bacteria among the composite substrates, which helps in rapidly catalyzing biochemical reactions.

\section{Effect of HRTon Nitrogen Removal by UVFCWs}
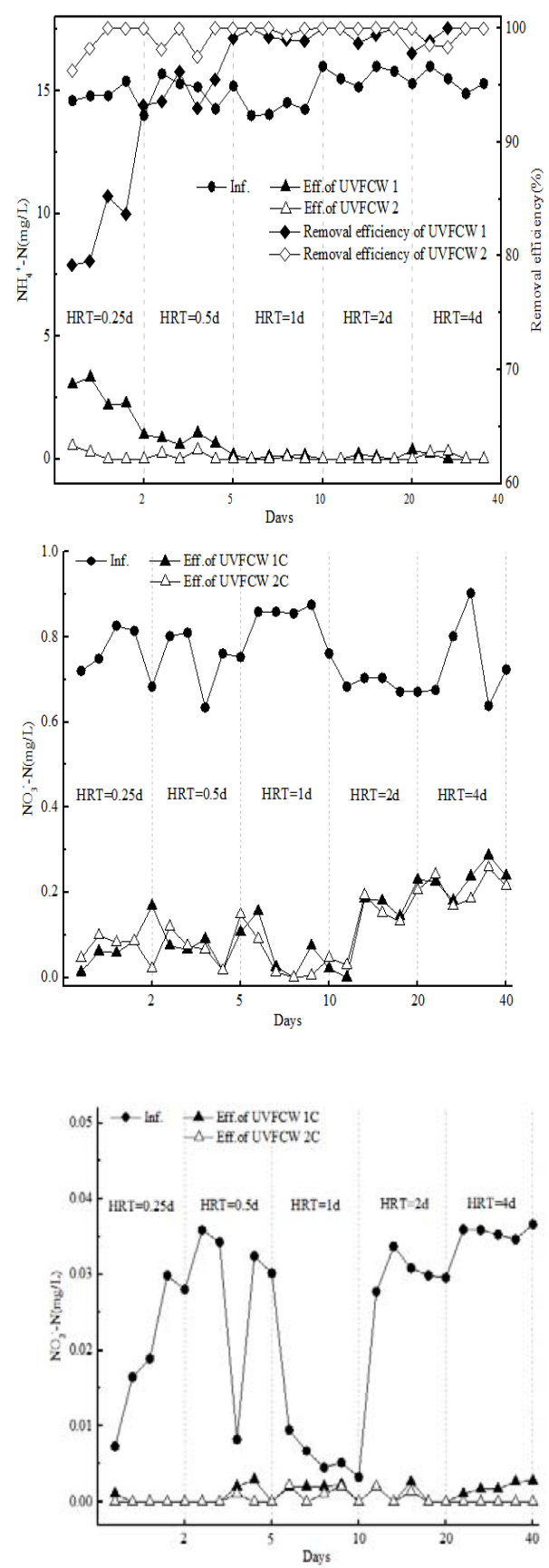

Figure 4. Effect of HRT on nitrogen removal by UVFCWs

The HRT plays a more significant role in the removal of nitrogen than COD, especially for removal of $\mathrm{NH}_{4}^{+}-\mathrm{N}$. The concentrations of $\mathrm{NH}_{4}{ }^{+}-\mathrm{N}$ in the effluent keep steady with an decrease in the HRT from 4 to $1 \mathrm{~d}$ but sharply increase with further decrease in HRT to shorter [7].Higher HRT implies lower loading and more contact time, which results in more efficient removal of $\mathrm{NH}_{4}{ }^{+}-\mathrm{N}$ and maintains the stability of the treatment efficiency (97\% to $99 \%$ ) during the monitoring period. With the HRT decrease to 1 day, the removal efficiency of UVFCWs- 1 decreases from $95 \%$ to $80 \%$.Unlike the UVFCWs-1, UVFCWs-2 shows a better performance with the removal efficiency fluctuating at $95 \pm 1 \%$. Which 
means that higher ratio of zeolite in the composite substrates is good for the $\mathrm{NH}_{4}{ }^{+}-\mathrm{N}$ removal, especially at lower HRT.

In our study, the higher HRT of 4 days resulted in maximum removal of $\mathrm{NH}_{4}{ }^{+}-\mathrm{N}$ and maintained the stability of the treatment efficiency the monitoring period. This is expected, since higher HRT implies lower loading and more contact time, and thus more stability in efficiency. The high ammonia removal was likely due to a combination of nitrification, denitrification and annamox in addition to biomass uptake.

The removal of $\mathrm{NH}_{4}^{+}-\mathrm{N}$ keeps in a high level, but both the concentration of $\mathrm{NO}_{3}^{-}-\mathrm{N}$ and $\mathrm{NO}_{2}^{-}-\mathrm{N}$ in the influents and effluents are at low levels. In view of the weak specific adsorption of $\mathrm{NO}_{3}{ }^{-}-\mathrm{N}$ and $\mathrm{NO}_{2}{ }^{-} \mathrm{N}$ by the composite substrates [8], the possible reason can attribute to a combination of nitrification, denitrification and annamox. Because in a vertical flow constructed wetland (as in the present study) an aerobic condition prevailed in the water layer just below the surface and anerobic condition in the deeper zone within the bed, the elimination of $\mathrm{NH}_{4}{ }^{+} \mathrm{N}$ from the wetland system could be attributed to nitrification at the surface layer. $\mathrm{NH}_{4}{ }^{+}-\mathrm{N}$ removal by annamox could take place in the deep layer of biofilms. Since anammox used nitrite as the electron acceptor, nitrate was first reduced to $\mathrm{NO}_{2}^{-}-\mathrm{N}$ and then both $\mathrm{NO}_{2}^{-}-\mathrm{N}$ and $\mathrm{NH}_{4}{ }^{+}-\mathrm{N}$ were lost through anammox process. This was more likely pathway considering the loss of large amounts of $\mathrm{NH}_{4}^{+}-\mathrm{N}$ together with $\mathrm{NO}_{3}{ }^{-} \mathrm{N}$, and the limitation on oxygen. Gumbricht (1993) assumed that denitrification occurs if oxygen was lacking. Facultative anaerobic bacteria use $\mathrm{NO}_{3}{ }^{-}$in place of free $\mathrm{O}_{2}$ as the terminal exogenous $\mathrm{H}^{+}$acceptor in respiration. Organic matter furnishes energy for growth of denitrifying bacteria and serves as $\mathrm{H}^{+}$donor in the denitrification process. Decreasing HRT supports the development of aerobic conditions and hindered denitrification processes. Nevertheless, highest HRT with lower oxygen contents promotes denitrification and thus highest $\mathrm{NO}_{3}$ removal.

\section{Effect of Depth and DO on Nitrogen Removal by UVFCWs}
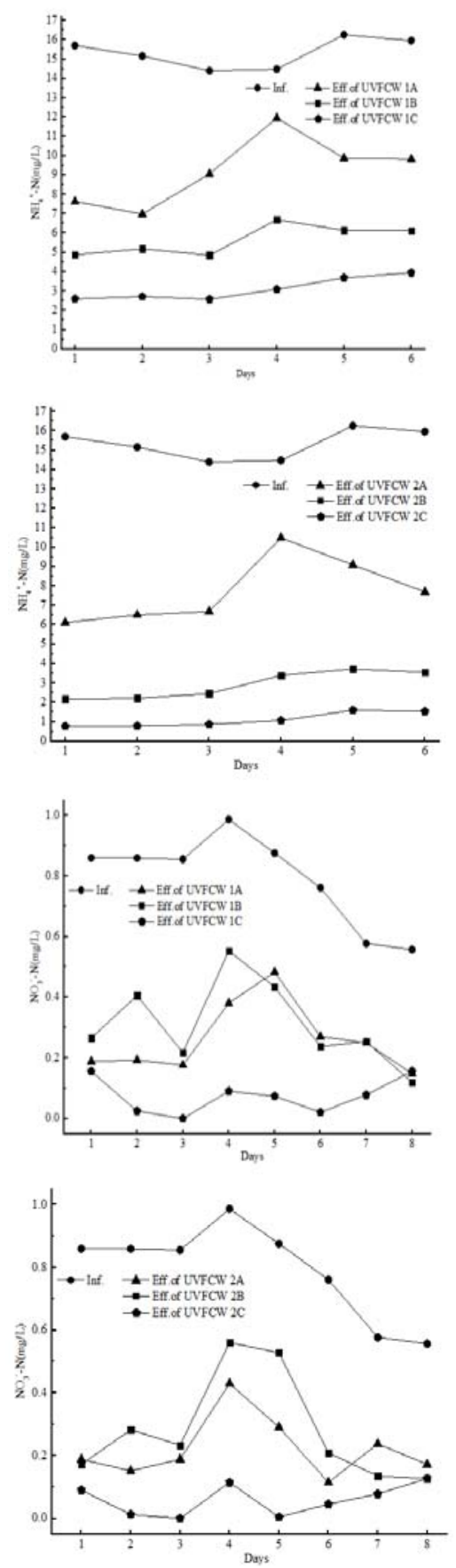

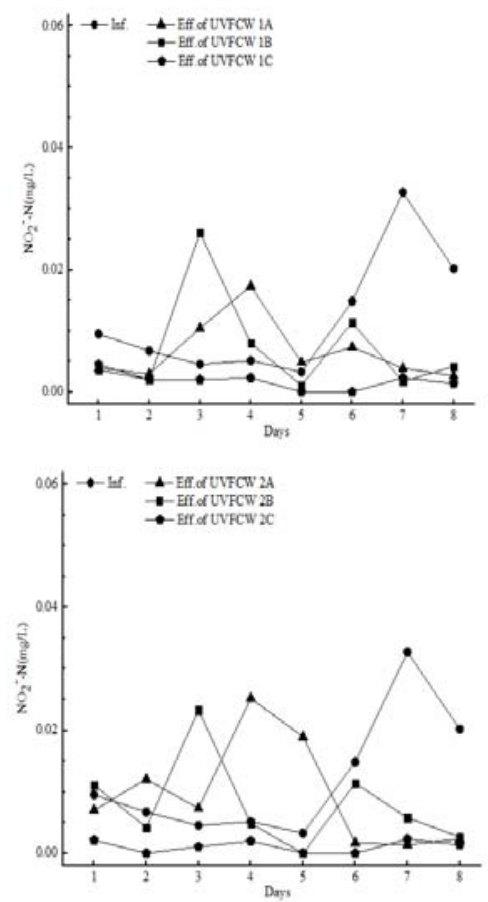

Figure 5. Effect of depth on nitrogen removal by UVFCWs

In view of the good nutrient removal performance of the UVFCWs at the HRT of one day, some further experiment are conducted to study the effect of depth and DO on nitrogen removal. The variations of $\mathrm{NO}_{3}{ }^{-} \mathrm{N}, \mathrm{NO}_{2}^{-}-$ $\mathrm{N}$, and $\mathrm{NH}_{4}^{+}-\mathrm{N}$ along the depth are shown in Fig.5.With the increase of the depth, the concentration of $\mathrm{NH}_{4}{ }^{+}-\mathrm{N}$ in the effluents of UVFCWs decreases obviously, with average removal efficiency of $50 \%, 70 \%$ and $90 \%$, respectively, in UVFCWs-2. Although the performance of UVFCWs-1shows the same trend, but the corresponding results are much lower than that of UVFCWs-2.

The concentration of $\mathrm{NO}_{3}^{-}-\mathrm{N}$ and $\mathrm{NO}_{2}^{-}-\mathrm{N}$ in the effluents of different sample points shows the same decreasing trend, but also of results are kept in very low level. It provides evidence for the hypothesis that most concentration of COD and the process of nitrification are accomplished during the first part of the composite substrates and the process of denitrification is in high level during the next two parts below. As a result, the concentration of $\mathrm{NH}_{4}^{+}-\mathrm{N}, \mathrm{NO}_{2}^{-}-\mathrm{N}$ and $\mathrm{NO}_{3}^{-}-\mathrm{N}$ are at a very low level in the bottom effluents [8].
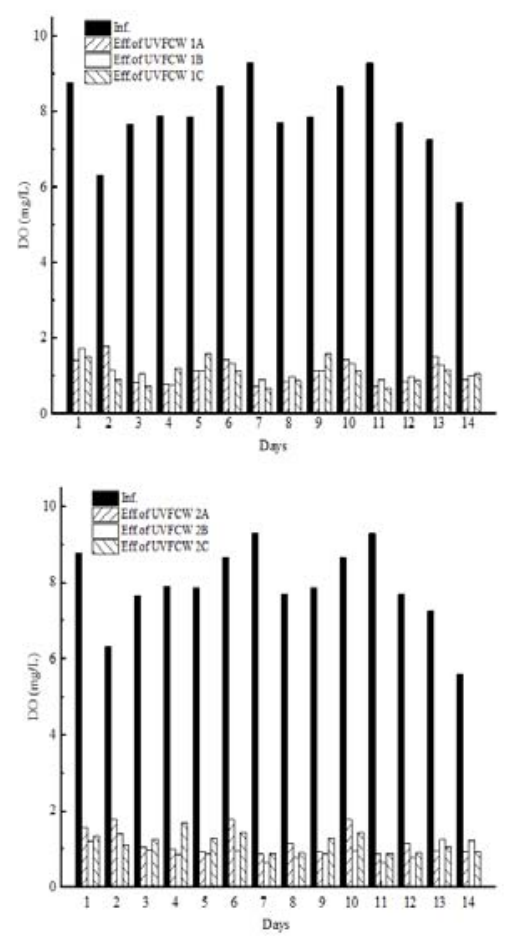

Figure 6. Effect of DO on nitrogen removal by UVFCWs

DO limitation is quite so common in VFCW treating nutrient or nitrogen load wastewaters wastewaters. It is generally accepted that DO concentrations above 1.5 $\mathrm{mg} / \mathrm{L}$ are essential for nitrification to occur. The DO detected at the influent varied from 6.4 to $8.6 \mathrm{mg} / \mathrm{L}$ in this experiment, while the DO detected at the effluent ranged from 0.5 to $1.5 \mathrm{mg} / \mathrm{L}$. Considering that part of the available DO will have been consumed in the oxidation of organic matter, the deficit of oxygen for nitrification would be greater. Due to the competition for oxygen consumption between the degradation of organics (COD) and the oxidation of ammonia, $\mathrm{NH}_{4}{ }^{+}-\mathrm{N}$ still existed after the first aerobic stage but remained at an extremely low level after further oxidation in the next aerobic stage [10]. It is indicated that the combination process of nitrification, denitrification and annamox will occur primarily under low DO content and anoxic stages.

\section{CONCLUSIONS}

To the composite substrates of zeolite and volcanic rock, prolonged contact time is in favor of COD removal, but the increasing ratio of zeolite has obviously negative effect on COD removal. Both of the prolonged contact time and the increasing ratio of zeolite have no remarkable effect on $\mathrm{NH}_{4}{ }^{+}-\mathrm{N}$ removal. Unvegetated vertical flow constructed wetlands (UVFCWs) constructed with zeolite and volcanic rock at weight ratio of $1: 1$ and $3: 1$, are efficient in nutrients removal from modeling effluent of secondary treatment process. At influent $\mathrm{COD} / \mathrm{N}$ ratios of 4.0 , the HRTs show no significant influence on the removal of COD, approximately $70 \%$ of COD removed by the UVFCWs. HRT plays a more significant role in the removal of $\mathrm{NH}_{4}^{+}-$ $\mathrm{N}$ than COD. Decreasing HRT results in lower removal 
efficiency of $\mathrm{NH}_{4}{ }^{+}-\mathrm{N}$. Higher ratio of zeolite in the composite substrates is good for the $\mathrm{NH}_{4}{ }^{+} \mathrm{N}$ removal in lower HRT. With HRT increased from $0.25 \mathrm{~d}$ to $4 \mathrm{~d}$, there is no significant difference in $\mathrm{COD}, \mathrm{NO}_{3}{ }^{-} \mathrm{N}$ and $\mathrm{NO}_{2}^{-}-\mathrm{N}$ removal efficiency. During the period of operation, the DO concentration is stable, but the concentrations of $\mathrm{NH}_{4}{ }^{+}-\mathrm{N}, \mathrm{NO}_{3}{ }^{-} \mathrm{N}$ and $\mathrm{NO}_{2}{ }^{-} \mathrm{N}$ keep at low levels. The high efficiency of the UVFCWs in $\mathrm{NH}_{4}^{+}-\mathrm{N}$ removal can be attributed to a combination process of nitrification, denitrification and annamox.

\section{ACKNOWLEDGEMENTS}

This work was supported by Major Science and Technology Program for Water Pollution Control and Treatment of China (2015ZX07204-002) and the National Natural Science Research Fund (No. 51278051).

\section{REFERENCES}

[1] L. H. Cheng, X. J. Bi, T. T. Jiang and C. Q. Liu, Effect of Ozone Enhanced Flocculation on the Treatment of Secondary Effluent, Procedia Environmental Sciences 10 (2011) 555-560

[2] Asano T, Levine AD. Wastewater reclamation, recycling and reuse: past, present and future. Water Sci.Technol.1996; 33(10-11):1-14.
[3] Vymazal, J., Kröpfelová, L., 2008. Types of constructed wetlands for wastewater treatment. In: Vymazal, J., Kröpfelováa, L. (Eds.), Wastewater Treatment in Constructed Wetlands with Horizontal Sub-Surface Flow. Springer, Inc., Netherlands, pp. 121-202, Chapter 4.

[4] Greenway, M., 1997. Nutrient content of wetland plants in constructed wet-lands receiving municipal effluent in tropical Australia. Water Sci. Technol. 35, 135-142.

[5] Vymazal, J., 2005. Horizontal sub-surface flow and hybrid constructed wetlands systems for wastewater treatment. Ecol. Eng. 25 (5), 478-490.

[6] Leilei Bai, Changhui Wang, Caihong Huang, Liansheng He, Yuansheng Pei, Reuse of drinking water treatment residuals as a substrate in constructed wetlands for sewage tertiary treatment.Ecol.Eng. 70 (2014) 295-303

[7] Deblina Ghosh, Brij Gopal.Effect of hydraulic retention time on the treatment of secondary effluent in a subsurface flow constructed wetland. Ecol. Eng. 36 (2010) 1044-1051

[8] Fengmin Li, Lun Lu, Xiang Zheng, Huu Hao Ngo, Shuang Liang, Wenshan Guo, Xiuwen Zhang, Enhanced nitrogen removal in constructed wetlands: Effects of dissolved oxygen and stepfeeding.Bioresource Technology 169 (2014) 395-402

[9] García J, Aguirre P., Barragán J, Mujeriego R, Matamoros V, Bayona, JM, Effect of key design parameters on the efficiency of horizontal subsurface flow constructed wetlands. Ecol.Eng 2005; 25:405-418.

[10] Caselles-Osorio, A., Garcia, J., 2006. Performance of experimental horizontal subsurface flow constructed wetlands fed with dissolved or particulate organic matter. Water Res. 40 (19), 3603-3611. 